\title{
Boş Zaman İlgilenim Faktörleri ile Fitness Merkezine Yönelik Tatmin ve Sadakat Arasındaki İlişki
}

\author{
The Relationship between Satisfaction and Loyalty Towards to \\ the Fitness Center with the Factors of Leisure Involvement
}

\author{
Gözde Yetim - Prof. Dr. Metin Argan
}

Başvuru Tarihi: 11.02.2015

Kabul Tarihi: 31.03.2017

\section{Öz}

Gelişen teknoloji sayesinde toplum yaşamı içerisinde çalışma saatleri kısalarak bireylerin boş zamanlarında artış meydana gelmiştir. Bu artış ile birlikte bireyler işten arta kalan boş zamanlarını değerlendirme arayışı içine girmişlerdir. Boş zamanlarında katılacakları etkinlikler bireyden bireye farkllik göstermektedir. Dolayısiyla bu durum ilgilenim konusunun önemine vurgu yapmaktadır. Özellikle yoğun rekabet ortamı içerisindeki fitness sektöründe, fitness merkezlerinin ayakta kalabilmesi için müşterilerin bireysel ilgilenim profillerini belirlemek oldukça önemli bir hal almaktadır. Çünkü ilgilenim, oluşturulmak istenen sadakatin öncüllerinden biri olarak değerlendirilebilir.

Bu çalışmanın amacı a) Boş zaman ilgilenim faktörlerini ortaya çıarmak, b) Boşzaman ilgilenimi ve fitness merkezine yönelik sadakat arasındaki ilişkiyi, c) Boş zaman ilgilenimi ve fitness merkezine yönelik tatmin arasındaki ilişkiyi, d) Fitness merkezine yönelik tatmin ve fitness merkezine yönelik sadakat arasındaki ilişkiyi incelemektir. Araştırma, Eskişehir ili sinırları içerisinden seçilen Sportif Club, Qualitasspa, Fitlife, Sablon Wellness Club ve Esjim fitness merkezlerindeki 658 üye ile gerçekleşmiştir. Çalışmada faktör analizi sonucunda fitness merkezi üyelerinin boş zaman ilgilenimini etkileyen altı faktör ortaya çıkmıştır. Bu faktörler çalışan davranışı, resepsiyon hizmetleri, temizlik/hijyen, ödeme ve teșvik, sağllk ve fitness ve kullanıma hazırlık olarak isimlendirilmiştir. Yapılan regresyon analizi sonucunda ödeme ve teşvik ( $\beta=0412 ; p<0,01)$ faktörü fitness merkezine yönelik tatmin ve sadakati üzerinde en güçlü etkiye sahiptir. Bunun yanında temizlik/hijyen ile sağlk ve fitness faktörlerinin fitness merkezine yönelik sadakat üzerinde anlaml bir etkisi olmadiğr ifade edilebilir.

Anahtar Kelimeler: Boş Zaman, Boş Zaman İlgilenimi, Fitness Merkezine Yönelik Tatmin, Fitness Merkezine Yönelik Sadakat

\begin{abstract}
Developing technology has decreased the working hours in public life and the leisure time was increased. This increase was occurred some alternatives for spending leisure time. Participating in leisure activities varies
\end{abstract}

Gözde Yetim, Anadolu Üniversitesi Sağlık Bilimleri Enstitüsü Yüksek Lisans Mezunu, gozdeey03@hotmail.com Prof. Dr. Metin Argan, Anadolu Üniversitesi Spor Bilimleri Fakültesi, margan@anadolu.edu.tr

* Bu çalıșma Anadolu Üniversitesi, Sağlık Bilimleri Enstitüsü Yönetim Kurulu’nun 16.07.2014 tarih ve 21 sayılı kararıyla onaylanan "Boș Zaman İlgileniminin Boş Zaman Tatmini ve Sadakati Üzerine Etkisi: Eskişehir'deki Fitnes Merkezleri Üzerine Araştırma” isimli Yüksek lisans tezinden türetilmiştir. 
from individual to individual. Therefore, involvement concept is gaining importance. Especially in fitness sector where there is intensive competition, fitness centers must determine their customers individual involvement profile. Because involvement is formed as one of precursors of loyalty.

The purpose of this study to examine; a) the impact of leisure involvement, $b$ ) the relationship between leisure involvement and loyalty towards to the fitness center, c) the relationship between leisure involvement and satisfaction towards to the fitness center, d) the relationship between satisfaction and loyalty towards to the fitness center. The study was occur with 658 members of five fitness centers in Eskişehir which is Sportif Club, Qualitasspa, Fitlife, Sablon Wellness Club and Esjim fitness centers. The result of factor analysis revealed six factors. These factors named with employee attitude, services of reception, cleaning/hygiene, payment and encouragement, health and fitness and preparation of use. The result of regression indicated that the factor of payment and encouragement $(\beta=0412 ; p<0,01)$ have a strong effect on satisfaction and loyalty towards to the fitness center. Besides, factors of cleaning/hygiene and health and fitness have any significant effect on loyalty towards to the fitness center.

Keywords: Leisure, Leisure Involvement, Satisfaction Towards to the Fitness Center, Loyalty Towards to the Fitness Center

\section{Giriş}

Çağın beraberinde getirdiği, gelişen endüstri ve teknoloji ile birlikte ortaya çıkan iş hayatında ve yaşam dünyasındaki büyük gelişmeler, çalışma saatlerini azaltarak yaşamı daha da kolaylaştırmakta ve bu da boş zamana olan ilginin artmasına olanak sağlamaktadır (Argan, 2007, s. 9). Bireylerin boş zamana karşı ilgilerinin artması ile birlikte, bireyler boş zamanlarını değerlendirme arayışına girmektedirler. Boş zaman değerlendirme tercihleri, bireylerin istek, ihtiyaç ve beklentilerine göre farklılık gösterdiğinden bu noktada ilgilenim konusu önem kazanmaktadır.
İşletmelerin, bireylerin boş zamanlarında meydana gelen bu artışı fırsat olarak görmeye başlaması da bu alanı ticari bir sektör haline getirmektedir. İşletmelerin yoğun rekabet ortamında ayakta kalabilmeleri için farklı taleplere sahip bireylere gerekli hizmeti verebilmek ve işletmeye karşı tatmin ve sadakat oluşumunu sağlamak adına, öncelikle bireylerin ilgilenimlerini bilmeleri önemli hale gelmeye başlamıştır.

Farklı ülkelerden birçok araştırmacı tarafından bu alanda çeşitli çalışmalar yapılmasına karşın (Havitz ve Dimanche, 1999; Lee ve Graefe, 2002; Funk vd., 2004; Decloe vd., 2009; Kontogianni, 2011; Chen vd., 2013; Tachis ve Tzetzis, 2015), Türkiyede boş zaman ilgilenimi alanında çok az çalışma olmasından dolayı bu araştırmanın böylesi bir eksikliği giderme konusunda boş zaman literatürüne katkı sağlayacağı düşünülmektedir. Dünyada her geçen gün hızla artan sağlıklı ve zinde olma gereksinimi bireyleri boş zamanlarında fitness merkezlerine yöneltmiştir (Tüfekçi, 2010, s.1). Hizmet sektörünün sürekli artan rekabet ortamında özellikle fitness merkezleri incelendiğinde, fitness merkezlerinin sayısının artması bireylerin hangi fitness merkezine üye olacaklarına karar verme aşamasında çeşitli zorluklara sebep olmaktadır. Benzer şekilde, herhangi bir fitness merkezine üye olan bireyin alternatifler arasindan doğru karar verip vermediği ve burada üyeliğini devam ettirme konusunda şüpheleri oluşmaktadır. Bu düşünceden hareketle bu çalışmada farklı istek, ihtiyaç ve beklentiler içinde olan bireylerin iş dışında kalan zamanlarda katılım gösterdikleri ve aynı zamanda ticari bir sektör haline gelen, Eskişehirde bulunan beş fitness merkezi ele alınmıştır.

İlgilenim kavramı ile ilgili literatüre katkı sağlayabileceğini düşündüğümüz bu çalışmanın amacı, fitness merkezine üye olan bireylerin boş zaman ilgilenim faktörlerini ortaya koyarak fitness merkezine yönelik tatmin ve sadakat arasındaki ilişkiyi değerlendirmeye yöneliktir. Aynı zamanda çalışma sonucunda ortaya çıkacak olan verilerin işletmelerin gelişimine katkı sağlayabileceği açısından da önemli olabileceği düşünülmektedir. Bu amaç doğrultusunda aşağıdaki soruya yanıt aranmıştır:

Fitness merkezi üyelerinin boş zaman ilgilenim faktörleri ile fitness merkezine yönelik tatmin ve sadakatleri arasında ilişki durumu nedir? 


\section{Kavramsal Çerçeve}

İlgilenim kavramı genellikle tüketici davranışı literatüründe kullanılmakla birlikte son yıllarda boş zaman ve rekreasyon araştırmacıları tarafından da kullanılmaya başlanmıştır (Jamrozy vd., 1996, s. 909910). İlgilenimi, bilgiyi işlemedeki güdülenme olarak görmek gerekir. Tüketici, ihtiyacını neyin tatmin edeceğini belirlemeye çalıştı̆̆ında, amacını gerçekleştirecek bilgilerin işlenmesine ve bunlara dikkat göstermeye güdülenmiş olacaktır (Odabaşı, 1998, s. 60). Genel anlamda ilgilenim, kişisel ilgi ya da herhangi bir aktiviteye karşı katılım gösterme tutumu ve bunlardan alınan zevk, eğlence ve heyecan olarak açıklanabilir (Decloe vd., 2009, s. 77). Boş zaman ilgilenimi ise bir eğlenceye, bir ürün satın almaya, ilgili ürün ve hizmetlerin kullanımına ya da katılım sıklığına bağlı rekreasyonel farkındalık olarak açıklanabilir (Kerstetler ve Kovich, 1997). Rothschild (1984)'in tanımlaması doğrultusunda boş zaman ilgilenimi, Funk vd. (2004, s. 36) tarafından "gözlemlenemeyen motivasyon hali, uyarılma ya da bir rekreasyon aktivitesine karşı duyulan ilgi” olarak belirtilmiştir. Havitz ve Dimance (1999) bireylerin rekreasyon aktivitelerine ilgilenimlerinin pozitif yönlü devam ettikçe, katılım davranışlarının da pozitif yönlü etkilenmekte olduğunu belirtmişlerdir.

Boş zaman ilgilenimi çekicilik, sembolik değer, risk olasıllğı ve risk sonuçları olarak dört boyuttan oluşurken, benzer şekilde rekreasyonel ilgilenim de çekicilik, sembolik değer, merkezilik ve risk olasılığını içeren çok yönlü bir yapıdan oluşmaktadır (Hsieh, 2007, s. 32). Çekicilik boyutu; sağlıklı çevre, eğlence ve heyecan gibi unsurları içerirken, merkezilik boyutu ise; toplumsallaşma ve arkadaşlarla bir arada olma gibi sosyal boyutları içermektedir (Kyle vd., 2006, s. 471). Risk olasılığı boyutunda bireyin yanlış seçim ya da satın alma kararı ihtimalinin algılanması söz konusu iken, risk sonucu boyutunda da ürünü ya da hizmeti satın alma durumuna ilişkin yanlış seçim yapma sonucu ortaya çıan olumsuz sonuçların algılanan önemi olarak ifade edilmektedir (Funk vd., 2004, s. 37).

İlgilenimi sürekli-durumsal ya da yüksek-düşük ilgilenim olarak iki türde incelemek mümkündür. Sürekli ilgilenim bireyin herhangi bir ürün ya da aktiviteye karşı her zaman var olan ilgisi olarak ifade edilirken (Assael, 1992, s. 30), durumsal ilgilenim bireyin ürün veya aktivite ile ilgili geçici bir süre için olan özel ilgisini göstermektedir (Koç, 2012, s. 209). Richins ve
Bloch (1986, s. 283)'un sürekli ilgilenim ile durumsal ilgilenim üzerine yaptıkları çalışma, sürekli ilgilenimin zaman içerisinde değişiklik göstermediğini, durumsal ilgilenim de ise satın alma davranışı gerçekleşene kadar dalgalanma olduğunu göstermektedir. Yüksek ilgilenimde birey ilgilendiği aktivite ile ilgili kapsamlı bilgiler araştırarak daha fazla zaman ve çaba harcar (Evans vd., 2006). Buna karşllık düşük ilgilenimde birey katılacağ 1 aktivitenin özelliklerini ya hiç araştırmaz ya da üstünkörü bilgi edinir (Karalar, 2011, s. 246). Yüksek ilgilenime sahip bireyler için doğru kararı vererek kendileri için doğru aktiviteye katılım davranışı sergilemek çok önemlidir bu yüzden aktiviteler hakkında arkadaşlarına, daha önce katılım göstermiş bireylere ve çevrelerindeki insanlara sorular sorar ve en iyi kararı vermeye çalışırlar (Koç, 2012, s. 213). Kyle vd. (2007) daha önce herhangi bir aktiviteye katılan bireyin, hiç katılmamış bir bireye göre aktivitelere katılım gösterme eğiliminin daha fazla olduğunu belirtmişlerdir.

Zaichkowsky (1985)'e göre düşük ilgilenime, boş zaman ilgilenimi perspektifinden bakıldığında;

- Aktiviteler ya da hizmet ile ilgili bilgi edinimi daha az gerçekleşir,

- Benzer aktivitelerle arasında daha az karşılaştırma yapilır,

- Diğer aktivitelerle benzer olduğu algısı yaratır,

- Belirli aktiviteler için herhangi özel bir tercih yoktur.

Beard ve Ragheb (1980, s. 22) boş zaman tatmini kavramını "bireyin oluşturduğu pozitif algı ya da duygular, boş zaman aktivite ve seçimleriyle ilgilenmenin bir sonucu olarak ortaya çıar" şeklinde tanımlamışlardır. Chen vd. (2013)'nın 701 Tayvanlı öğrenci ile yaptığ 1 çalışmada boş zaman ilgileniminin, boş zaman tatmini üzerinde pozitif bir etkisi olduğunu ifade etmişlerdir. Tuu ve Olsen (2010) ise 922 Vietnamlı tüketici üzerinde yaptıkları çalışmada, tatminin tekrar satın alma sadakati ve ilgilenim üzerinde direkt ya da dolaylı olarak pozitif bir etkisi olduğunu bulmuşlardır. Olsen (2007) çalışmasında ilgilenimin tekrar satın alma sadakatini pozitif yönde etkilerken, tatminin ise ilgilenimi pozitif yönde etkilediğini ortaya koymuştur. 
Boş zaman sadakati, bireylerin ilgi duydukları markaya ya da aktiviteye karşı ve aynı markayı satın alırken ya da aynı aktiviteye katılırken gösterdikleri tutum ve davranışlarını yansıtmaktadır (Iwasaki ve Havitz, 2004). Bunun yanında, sadakatin bir kişiye, duruma ya da herhangi bir ürüne karşı gösterdikleri ısrarlı bağlllık olduğu ileri sürülmüş ve sadakatin, kişinin bunlara karşı olan tutum ve davranışlarını yansıttığı belirtilmiştir (Kontogianni, 2011).

Lee ve Graefe (2002) ilgilenim ve sadakat arasındaki ilişkiyi incelemiş ve sonuç olarak ilgilenimin doğrudan veya dolaylı olarak sadakat üzerinde etkili olduğunu bulmuşlardır. Ayrıca ilgilenimin, sadakatin en önemli öncülü olduğunu belirterek, sadakati açıklarken ilgilenimin önemine vurgu yapmışlardır. Park (1996) 208 yetişkin fitness programı katılımcısı üzerinde yaptığı çalışma da sadakat ile ilgilenim profilleri arasında önemli ve güçlü bir ilişkinin olduğunu göstermektedir. Zetou vd. (2013) Atina' da 521 voleybol izleyicisi üzerinde taraftar ilgileniminin rolü üzerine yaptıkları araştırmada ilgilenim ile sadakat arasında pozitif yönlü bir ilişki olduğu ortaya çımıştır.

Çat1 ve Koçoğlu (2008), müşteri tatmini ile müşteri sadakati arasındaki ilişkiyi belirlemeye yönelik yap- tıkları çalışmalarında, müşteri tatmininde etkili olan faktörlerin müşteri sadakati üzerinde de etkili oldugunu vurgularken, Castaneda (2011) da internet üzerine yaptığı araştırmada tatminin sadakat üzerinde pozitif etkisi olduğunu ifade etmiştir.

Mechinda vd. (2008) tatminin, bireyin karar verdiği seçeneğe ya da kararından geri dönmesine etki ettiği için sadakati belirlemede çok önemli rol oynadığını ifade etmişlerdir. Ayrıca birey tatmin olmuşsa aynı ürünü satın almaya devam etmesi muhtemel iken, tatmin olmamışsa diğer alternatif ürünlere yönelmesinin söz konusu olduğunu belirtmişlerdir. Yukarıda ifade edilen ilişkiler doğrultusunda oluşturulan hipotezlerin şematik durumunu gösteren kuramsal araştırma modeli aşağıda verilmiştir.

H1: Boş zaman ilgilenimi ile fitness merkezine yönelik tatmin arasında ilişki vardır.

H2: Boş zaman ilgilenimi ile fitness merkezine yönelik sadakat arasında ilișki vardır.

H3: Fitness merkezine yönelik tatmin ile fitness merkezine yönelik sadakat arasında ilişki vardır.

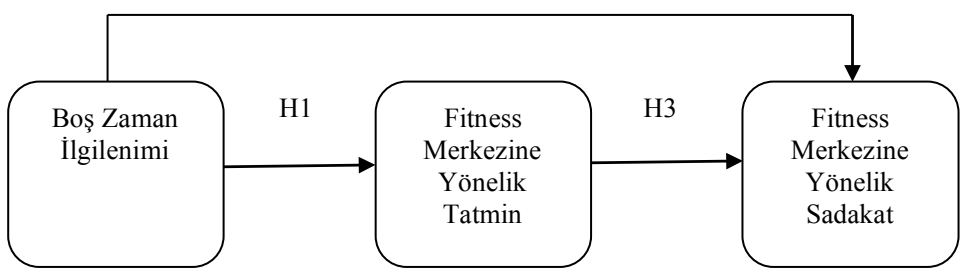

Şekil 1. Kuramsal Araştırma Modeli

\section{Araştırmanın Yöntemi}

Bu çalışmada amaç, fitness merkezi üyelerinin boş zaman ilgilenim faktörlerini ortaya çıararak bu faktörlerin fitness merkezine yönelik tatmin ve sadakat ile ilişkisini incelemektir. Araştırmada, Jung (2007)'un kullanmış olduğu anket araştırma amacı doğrultusunda uyarlanarak bu çalışmada kullanılmıştır. Anket 4 bölümden oluşmaktadır. Birinci bölümde boş zaman ilgilenimini ölçmek amacıyla 30 ifade bulun- maktadır. İkinci bölümde fitness merkezine yönelik sadakati ölçmek amacıyla 16 ifade, üçüncü bölümde fitness merkezine yönelik tatmini ölçmek amacıyla 6 ifade bulunmaktadır. İlk üç bölüm beşli Likert Ölçeği ile (“5” kesinlikle katılıyorum, "1" kesinlikle katılmıyorum) ile değerlendirilmiştir. Son bölümü ise katılımcıların demografik özelliklerine ilişkin sorular oluşturmaktadır. Bu bölümdeki sorular ise nominal ölçek ile değerlendirilmiştir. 
Bu çalışmanın evrenini, Eskişehir ili sınırları içerisindeki fitness merkezlerindeki üyeler oluşturmaktadır. Örneklemi ise Eskișehir'de bulunan Sportif Club, Qualitasspa, Fitlife, Sablon Wellness Club ve Esjim olmak üzere beș fitness merkezi oluşturmaktadır. Söz konusu beş fitness merkezi Eskişehir'deki $1000 \mathrm{~m}^{2}$ ve üzerinde alana sahip olanlar arasından seçilmiştir. Araştırmanın pilot çalışması 06-12 Mayıs 2013 tarihleri arasında Spor Bilimleri Fakültesi Spor Salonunda fitness üyesi olan 200 kişi ile gerçekleştirilip son şekli verilmiştir. Nihai araştırma verileri 5 Kasım 2013- 26 Ocak 2014 tarihleri arasında toplanmıştır ve bu tarihler arasında beş fitness merkezindeki toplam üye sayısı yaklaşık 2500 dür. Beş fitness merkezine toplam 686 anket dağıtılmış ve 658 anket değerlendirmeye alınmıştır. Yirmi sekiz anket eksik ya da hatalı olduğu için değerlendirmeye alınmamıştır. Dağıtılan anket bazında geri dönüş oranı \% 95,9 olarak gerçekleşmiştir. Anketler çalışma amacının belirtilmesinin ardından araştırmaya katılmayı gönüllü olarak kabul eden fitness merkezi üyelerine dağıtılmış ve kişi yönelimli (self administrated) teknik ile elde edilmiştir. Bu teknikte anketörler anket formlarını örneklem grubuna dağıtır ve sorular bu grup içerisindeki kişiler tarafından tek tek okuyarak cevaplandırılır (Kurulgan ve Argan, 2006). Araştırma için alanında eğitim almış beş anketör kullanılmıştır. Anketin cevaplanma süresi yaklaşık 10-15 dakika sürmüştür. Araştırmada olasılıklı olmayan örnekleme yöntemlerinden biri olan kolayda örnekleme yöntemi kullanılmıştır. Bu örneklemede amaç, kolayca ulaşılabilir birimlerin seçilmesiyle örneklemin oluşturulması olup (Özmen, 2006, s. 177), bu örneklemede sadece ulaşılabilir birimler örnekleme dahil edilir (Gegez, 2007, s. 249). Örneğin; uygun görülen sokaktan, uygun görülen zamanda gelip geçen bireylerle görüşme yapılması ya da konferansa katılan belirli sayıdaki katılımcıdan araştırma konusuyla ilgili görüşlerin alınması, birer kolayda örnekleme uygulamasıdır (Özmen, 2006, s. 177). Bu nedenle araştırma, yapıldığı tarih ve saat aralığında fitness merkezine gelen üyelerle gerçekleştirilmiştir.

\section{Bulgular ve Değerlendirme}

Araştırmaya katılan 658 katılımcının \% 31,9'u kadın, $\%$ 68,1'i erkektir. Katılımcıların \% 49,4'ü 18-25 yaş, 31,6'sı 26-35 yaş, \% 19 'u 36 yaş ve üzeri yaş grubun- dan oluşmaktadır. Bunların \% 71,7'sini üniversite (ön lisans/lisans) eğitim düzeyine sahip katılımcılar oluştururken, \% 17,2'sini lise veya daha düşük, \% 11,1'ini de lisansüstü (yüksek lisans/doktora) eğitim düzeyine sahip katılımcılar oluşturmaktadır. Araştırma katılımcılarının \% 40,6'sı öğrenci ve \% 72,9'u bekardir. Katılımciların \% 26,6’s1 1001-2000 TL, \% 23,5’i 1000 TL veya daha düşük, \% 20,2'si 2001-3000 TL, $\% 16,6$ 's1 4001 TL ve daha yüksek ve \% 13,1'i 3001$4000 \mathrm{TL}$ arası aylık ortalama gelir durumuna sahiptir (Tablo 1.).

Fitness merkezine üye olan bireylerin boş zaman ilgilenimlerini etkileyen faktörleri değerlendirmek için toplam 28 ifadenin gruplandırılması, sınıflandırılmas1 ve ana faktörlere dönüştürülmesi amaciyla Açıklayıcı Faktör Analizi (Explanatory Factor Analysis) uygulanmıştır. Faktör yükleri için alt sınır 0,40 olarak belirlenmiş ve buna göre iki ifade 0,40 ' $1 n$ altında olduğu için değerlendirmeye alınmamıştır. Yapılan analiz sonuçlarına ilişkin bulgular Tablo 2'de verilmiştir.

Tablo 2 incelendiğinde fitness merkezi üyelerinin boş zaman ilgilenimlerini etkileyen altı faktör ortaya çıkmıştır. Birinci faktör yedi değişkenden oluşmakta olup "çalışan davranışı", ikinci faktör beş değişkenden oluşmakta olup "resepsiyon hizmetleri”, üçüncü faktör beş değişkenden oluşup "temizlik/hijyen", dördüncü faktör beş değişkenden oluşmakta olup "ödeme ve teşvik", beşinci faktör dört değişkenden oluşup "sağllk ve fitness" ve son faktör olan altınc1 faktör iki değişkenden oluşmakta olup "kullanıma hazır$l \imath k$ " olarak isimlendirilmiştir. Fitness merkezine üye olan araştırma katılımcılarının boş zaman ilgilenim düzeylerine ilișkin faktör analizinde Kaiser-MeyerOlkin (KMO) ve Bartlett Test for Sphericity (BTS) değerlerine bakılmıştır. KMO katsayısı, verilerin ve örneklem büyüklüğünün seçilen analize uygun ve yeterli olduğunu belirlemede kullanılan istatistiksel bir yöntemdir (Pektaş vd., 2009). Yapılan bu araştırmada KMO 0,910 olup, faktör analizinin uygulanabilmesi için bu oran yeterlidir. BTS ise 6968,381 (p< 0,01 ) olarak saptanmıştır. Ortaya çıkan altı faktörün ve toplam ölçek güvenilirlik katsayılarının 0,70'den (Nunnally ve Bernstein, 1994, s. 32-34) büyük olmas1 güvenilir olduğunun işareti olarak değerlendirilebilir. 
Tablo 1. Araştırma Katılımcılarına ilişskin Demografik Özellikler

\begin{tabular}{|c|c|c|}
\hline & $\mathbf{N}$ & $\%$ \\
\hline $\begin{array}{l}\text { Cinsiyet } \\
\text { Kadin } \\
\text { Erkek }\end{array}$ & $\begin{array}{l}210 \\
448\end{array}$ & $\begin{array}{l}31,9 \\
68,1\end{array}$ \\
\hline $\begin{array}{l}\text { Yaş } \\
18-25 \\
26-35 \\
36-45 \\
46 \text { ve üstü } \\
\end{array}$ & $\begin{array}{c}325 \\
208 \\
75 \\
50 \\
\end{array}$ & $\begin{array}{c}49,4 \\
31,6 \\
11,4 \\
7,6 \\
\end{array}$ \\
\hline $\begin{array}{l}\text { Ĕgitim Durumu } \\
\text { Lise veya daha }< \\
\text { Üniversite (Ön Lisans/Lisans) } \\
\text { Lisansüstü (Yüksek Lisans/ Doktora) }\end{array}$ & $\begin{array}{c}113 \\
472 \\
73 \\
\end{array}$ & $\begin{array}{l}17,2 \\
71,7 \\
11,1 \\
\end{array}$ \\
\hline $\begin{array}{l}\text { Meslek } \\
\text { Memur } \\
\text { İşçi } \\
\text { Emekli } \\
\text { Ev Hanımı } \\
\text { Yönetici } \\
\text { Esnaf } \\
\text { Serbest Meslek } \\
\text { Öğrenci } \\
\text { Mühendis } \\
\text { Diğer }\end{array}$ & $\begin{array}{c}82 \\
46 \\
12 \\
29 \\
45 \\
34 \\
52 \\
267 \\
31 \\
60\end{array}$ & $\begin{array}{c}12,5 \\
7,0 \\
1,8 \\
4,4 \\
6,8 \\
5,2 \\
7,9 \\
40,6 \\
4,7 \\
9,1\end{array}$ \\
\hline $\begin{array}{l}\text { Medeni Durum } \\
\text { Bekar } \\
\text { Evli } \\
\text { Diğer }\end{array}$ & $\begin{array}{c}478 \\
174 \\
4 \\
\end{array}$ & $\begin{array}{c}72,9 \\
26,5 \\
0,6\end{array}$ \\
\hline $\begin{array}{l}\text { Aylık Ortalama Gelir Durumu } \\
1000 \text { TL veya daha }< \\
1001-2000 \text { TL } \\
2001-3000 \text { TL } \\
3001-4000 \text { TL } \\
4001 \text { TL ve daha }>\end{array}$ & $\begin{array}{c}154 \\
174 \\
132 \\
86 \\
109\end{array}$ & $\begin{array}{l}23,5 \\
26,6 \\
20,2 \\
13,1 \\
16,6\end{array}$ \\
\hline
\end{tabular}


Tablo 2. Boş Zaman IIgilenim Faktörleri

\begin{tabular}{|c|c|c|c|c|c|c|}
\hline Faktörler & Ort. & S.S. & $\begin{array}{l}\text { Faktör } \\
\text { Yükleri }\end{array}$ & Özdeğer & $\begin{array}{c}\text { Açıklanan } \\
\text { Varyans }\end{array}$ & $\begin{array}{c}\text { Alpha } \\
(\alpha)\end{array}$ \\
\hline $\begin{array}{l}\text { Çalışan davranışı } \\
\text {-Fitness eğitmenlerinden memnunum } \\
\text {-Çalışanlar bilgili, profesyonel ve kibardır } \\
\text {-Çalışanlar yardım konusunda istekli ve } \\
\text { ihtiyaçlarımı karşılamaya özen gösterir } \\
\text {-Grup dersleri bilgili, profesyonel ve uzman } \\
\text { fitness eğitmenleri tarafından veriliyor } \\
\text {-Fitness çalışanları sıcak davranır } \\
\text {-İhtiyacım olduğunda çalışanlar yardımcı } \\
\text { olur } \\
\text {-Fitness çalışanları işlerinde profesyoneldir }\end{array}$ & $\begin{array}{l}4,1429 \\
4,1565 \\
4,1520 \\
\\
3,9833 \\
4,3313 \\
4,3963 \\
4,1581\end{array}$ & $\begin{array}{r}, 86411 \\
, 84659 \\
, 85190 \\
\\
, 78496 \\
, 71489 \\
, 67332 \\
, 78955 \\
\end{array}$ & $\begin{array}{l}, 755 \\
, 738 \\
, 798 \\
\\
, 660 \\
\\
, 555 \\
, 593 \\
\end{array}$ & 3,937 & 14,061 & ,897 \\
\hline $\begin{array}{l}\text { Resepsiyon Hizmetleri } \\
\text {-Resepsiyon çalışanları sıcak davranır } \\
\text {-Resepsiyon verimli çalışır } \\
\text {-Resepsiyon çalışanları işlerinde } \\
\text { profesyoneldir } \\
\text {-Burayı telefonla aradığımda çok kibar } \\
\text { karşılanırım } \\
\text {-Resepsiyon çalışanları bütün sorularımı } \\
\text { cevaplayabilecek düzeydedir }\end{array}$ & $\begin{array}{r}4,3720 \\
4,2204 \\
4,0198 \\
\\
3,9633 \\
\\
4,0502\end{array}$ & $\begin{array}{l}, 80195 \\
, 82673 \\
, 81532 \\
\\
, 85836 \\
\\
, 81402\end{array}$ & $\begin{array}{l}, 815 \\
, 865 \\
, 778 \\
\\
, 688 \\
\end{array}$ & 3,579 & 12,782 &, 883 \\
\hline $\begin{array}{l}\text { Temizlik/ Hijyen } \\
\text {-Duşlar temizdir } \\
\text {-Soyunma odaları temiz ve yeterli } \\
\text { donanımdadır } \\
\text {-Sauna temizdir } \\
\text {-Havlu hizmetleri yeterli ve uygundur } \\
\text {-Soyunma odalarında tuvalet kağıdı, sabun, } \\
\text { el havlusu gibi malzemeler her zaman } \\
\text { mevcuttur }\end{array}$ & $\begin{array}{l}3,8739 \\
3,7568 \\
\\
4,1165 \\
3,6084 \\
3,8565\end{array}$ & $\begin{array}{l}1,13779 \\
1,15937 \\
\\
, 89440 \\
1,19469 \\
1,20048\end{array}$ & $\begin{array}{l}, 805 \\
, 795 \\
\\
, 712 \\
, 609 \\
, 664\end{array}$ & 2,954 & 10,549 & ,781 \\
\hline $\begin{array}{l}\ddot{O d e m e ~ v e ~ T e s ̧ v i k ~} \\
\text {-Buraya üye olduğum için mutluyum } \\
\text {-Buranın üyelik ücretlerinin makul olduğunu } \\
\text { düşünüyorum } \\
\text {-Üyelik ücretleri artsa bile yine de burayı } \\
\text { tercih etmeye devam edeceğim } \\
\text {-Başkalarına da burayı tavsiye edeceğim } \\
\text {-Boş zamanımın büyük bir bölümünü burada } \\
\text { geçiriyorum }\end{array}$ & $\begin{array}{l}4,3435 \\
3,7705 \\
\\
3,1869 \\
4,3085 \\
3,3009\end{array}$ & $\begin{array}{c}, 68954 \\
, 94470 \\
1,09795 \\
\\
, 76289 \\
1,01317\end{array}$ & $\begin{array}{l}, 617 \\
, 752 \\
, 786 \\
, 598 \\
, 472\end{array}$ & 2,641 & 9,433 &, 723 \\
\hline $\begin{array}{l}\text { Sağllk ve Fitness } \\
\text {-Burası benim kardiyo, kuvvet, esneklik } \\
\text { antrenman ihtiyacımı karşılar } \\
\text {-Koşu bandı ve bisiklet gibi kardiyo } \\
\text { ekipmanların kullanımı kolay ve yeterlidir } \\
\text {-Fitness ekipmanların kullanımı kolay ve } \\
\text { yeterlidir } \\
\text {-Burası aerobik, kuvvet ve esneklik gibi } \\
\text { çeşitli antrenman hizmetleri sunar }\end{array}$ & $\begin{array}{l}4,4444 \\
4,3191 \\
4,2226 \\
4,2462\end{array}$ & $\begin{array}{l}, 66971 \\
, 77732 \\
, 80029 \\
, 72372\end{array}$ & $\begin{array}{l}, 668 \\
, 804 \\
, 763 \\
, 567\end{array}$ & 2,563 & 9,155 & ,788 \\
\hline $\begin{array}{l}\text { Kullanıma Hazırlık } \\
\text {-Fitness çalışanları egzersiz alanını temiz } \\
\text { tutar } \\
\text {-Fitness çalışanları ekipmanların } \\
\text { kullanılabilirliği konusunda özen gösterir }\end{array}$ & $\begin{array}{l}4,1505 \\
4,1444\end{array}$ & $\begin{array}{l}, 88287 \\
, 79120\end{array}$ & $\begin{array}{l}, 707 \\
, 749\end{array}$ & 1,992 & 7,113 & ,782 \\
\hline \multicolumn{4}{|l|}{ Toplam Açıklanan Varyans } & & 63,093 & \\
\hline
\end{tabular}

Ort: Ortalama; S.S.: Standart Sapma; (“5” Kesinlikle Kat1lyorum; "1" Kesinlikle Katılmıyorum)

Fitness merkezine üye olan araştırma katılımcılarının boş zaman ilgilenimlerine ilişkin ortaya çıkan altı faktörün kendi aralarındaki korelasyon matrisi incelendiğinde; tüm faktörler arasında anlamlı bir ilişkinin olduğu $(\mathrm{p}<0,01)$ görülmektedir. Tablo 3 'te verilen boş zaman ilgilenim faktörlerine ilişkin aritmetik ortalama ve standart sapmalar incelendiğinde; sağlık ve fitness faktörü 4,3081 (S.S.= 0,58108) ortalama ile diğer faktörler arasında en yüksek ortalamaya sahiptir. 
Tablo 3. Boş Zaman IIgilenim Faktörleri Arasındaki Korelasyon Matrisi

\begin{tabular}{|l|c|c|c|c|c|c|c|c|}
\hline Faktörler & $\mathbf{1}$ & $\mathbf{2}$ & $\mathbf{3}$ & $\mathbf{4}$ & $\mathbf{5}$ & $\mathbf{6}$ & $\mathbf{O r t .}$ & S.S. \\
\hline Çalı̧̧an Davranışı & 1 & & & & & & 4,1884 &, 62275 \\
\hline Resepsiyon Hizmetleri &, $538^{* *}$ & 1 & & & & & 4,1256 &, 67873 \\
\hline Temizlik/ Hijyen &, $341^{* *}$ &, $342^{* *}$ & 1 & & & & 3,7339 &, 97821 \\
\hline Ödeme ve Teșvik &, $526^{* *}$ &, $376^{* *}$ &, $191^{* *}$ & 1 & & & 3,7821 &, 62984 \\
\hline Sağlık ve Fitness &, $549^{* *}$ &, $420^{* *}$ &, $386^{* *}$ &, $433^{* *}$ & 1 & & 4,3081 &, 58108 \\
\hline Kullanıma Hazırlık &, $520^{* *}$ &, $456^{* *}$ &, $516^{* *}$ &, $267^{* *}$ &, $402^{* *}$ & 1 & 4,1474 &, 75972 \\
\hline
\end{tabular}

** $\mathrm{p}<0,01 ; \quad(5=$ Kesinlikle Katılıyorum, $1=$ Kesinlikle Katılmıyorum $) ;$ Ort.: Ortalama, S.S.: Standart Sapma $\mathrm{n}=658$

Fitness merkezine üye olan katılımcıların fitness merkezine yönelik sadakat ve tatmin durumlarını değerlendirebilmek için toplam 16 ifadenin gruplandırılması, sınıflandırılması ve ana faktörlere dönüştürülmesi amacıyla yapılan Açıklayıcı Faktör Analizi (Explanatory Factor Analysis) sonucunda "sadakat" ve "tatmin" olarak isimlendirilen iki faktör ortaya çıkmıştır. Sadakat içerisindeki altı madde 0,40 ’’n altında olduğu için faktör analizine dahil edilmemiştir.
Katılımcıların fitness merkezine yönelik sadakat ve tatmin düzeylerine ilişkin faktör analizinde KMO ve BTS değerlerine bakılmıştır. Yapılan bu araştırmada KMO 0,924 olup, faktör analizinin uygulanabilmesi için bu oran yeterlidir. BTS ise 5152,084 $(\mathrm{p}<0,01)$ olarak saptanmıştır. Yapılan faktör analizi sonucunda iki faktöre ayrılan 16 ifadenin toplam güvenilirliği (Cronbach alpha $=\alpha$ ) 0,92 olarak bulunmuştur.

Tablo 4. Fitness Merkezine Yönelik Sadakat ve Tatmin Faktörleri

\begin{tabular}{|c|c|c|c|c|c|c|}
\hline Faktörler & Ort & S.S. & $\begin{array}{c}\text { Faktör } \\
\text { Yükleri }\end{array}$ & Özdeğer & $\begin{array}{c}\text { Açıklanan } \\
\text { Varyans }\end{array}$ & $\begin{array}{c}\text { Alpha } \\
(\alpha)\end{array}$ \\
\hline $\begin{array}{l}\text { Sadakat } \\
\text { Zamanımın büyük bir bölümünü burada geçirmekten mutluyum } \\
\text { Daha iyi bir alternatif bulsam bile buradan ayrılmayacağımı } \\
\text { düşünüyorum } \\
\text { Buradan ayrılmak avantajıma bile olsa buradan ayrılmayı istemem } \\
\text { Kendimi bu ailenin bir parçası olarak görüyorum } \\
\text { Burada bulunmak için büyük istek duyuyorum } \\
\text { Buradan başka bir fitness merkezine geçmeyi etik/ ahlaki } \\
\text { bulmuyorum } \\
\text { Bu fitness merkezine bağlılık arzusu hissediyorum } \\
\text { Kişisel olarak buraya ait olduğumu hissediyorum } \\
\text { Burası bana güçlü bir aitlik duygusu veriyor } \\
\text { Buradan ayrılmak zor olduğu için buraya gelmeye devam } \\
\text { ediyorum }\end{array}$ & $\begin{array}{l}3,9331 \\
3,2295 \\
\\
2,9833 \\
3,2325 \\
3,5030 \\
2,4894 \\
\\
\\
3,0881 \\
2,9635 \\
2,8216 \\
2,4590\end{array}$ & $\begin{array}{c}, 85569 \\
1,21780 \\
1,24772 \\
1,11679 \\
1,05156 \\
1,26204 \\
1,15000 \\
1,19685 \\
1,17489 \\
1,15693\end{array}$ & $\begin{array}{l}\text {,484 } \\
, 584 \\
\\
, 737 \\
, 783 \\
, 714 \\
, 725 \\
\\
, 791 \\
, 788 \\
, 816 \\
, 675\end{array}$ & 5,417 & 33,856 & ,898 \\
\hline $\begin{array}{l}\text { Tatmin } \\
\text { Buradan ve sunduğu olanaklardan memnunum } \\
\text { Buranın hizmet kalitesinin tamamından memnunum } \\
\text { Buranın sunduğu yiyecek-içecek kalitesinden memnunum } \\
\text { Buranın sunduğu boş zaman deneyiminden memnunum } \\
\text { Buradan elde ettiğim deneyimler faydalıdır } \\
\text { Burası beklentilerimi karşllamaktadır }\end{array}$ & $\begin{array}{l}4,2720 \\
3,9970 \\
3,7355 \\
3,9559 \\
4,1596 \\
4,2477\end{array}$ & $\begin{array}{l}, 71119 \\
, 88793 \\
, 96723 \\
, 88941 \\
, 80924 \\
, 71579\end{array}$ & $\begin{array}{l}, 858 \\
, 824 \\
, 652 \\
, 768 \\
, 699 \\
, 841\end{array}$ & 4,219 & 26,368 &, 887 \\
\hline Toplam Acıklanan Varyans & & & & & 60,225 & \\
\hline
\end{tabular}

Katılımcıların fitness merkezine yönelik sadakat ve tatminine ilişkin ortaya çıkan faktörlerin kendi aralarındaki korelasyon matrisi analizinde iki faktör arasında anlamlı bir ilişsinin olduğu $(\mathrm{p}<0,01)$ ortaya çıkmaktadır. Faktörlere ilişkin ortalamalar incelendiğinde 4,0638 (S.S.= ,65973) ortalama ile tatmin faktörü sadakat faktörüne göre daha yüksek ortalamaya sahiptir. 


\section{Tablo 5. Fitness Merkezine Yönelik Sadakat ve Tatmin Faktörleri Arasındaki Korelasyon Matrisi}

\begin{tabular}{|l|c|c|c|c|}
\hline Faktörler & $\mathbf{1}$ & $\mathbf{2}$ & Ort. & S.S. \\
\hline Sadakat & 1 & & 3,0705 &, 86228 \\
\hline Tatmin &, $552^{* *}$ & 1 & 4,0638 &, 65973 \\
\hline
\end{tabular}

${ }^{* *} \mathrm{p}<0,01 ;(5=$ Kesinlikle Katıllyorum, $1=$ Kesinlikle Katılmıyorum $)$; Ort.: Ortalama, S.S.: Standart Sapma

Katılımcılarının boş zaman ilgilenimleri ve fitness merkezine yönelik tatminleri arasındaki ilişkileri belirlemek amaciyla çoklu regresyon analizi uygulanmış ve boş zaman ilgilenimlerine ilişkin faktörlerin fitness merkezine yönelik tatmin üzerine etkisini ortaya koyan regresyon analiz $(\mathrm{F}=121,953 ; \mathrm{p}<0,01)$ değerleri göz önüne alındığında istatistiksel açıdan anlamlı bulunmuştur. Regresyona ilişkin standardize edilmiş beta $(\beta)$ değerleri incelendiğinde; ödeme ve teşvik $(\beta=0,412 ; p<0,01)$ faktörü fitness merkezine yönelik tatmin üzerinde en güçlü etkiye sahiptir.

Tablo 6. Katılımcıların Boş Zaman IIIgilenimlerinin Fitness Merkezine Yönelik Tatmin Üzerine Etkisi

\begin{tabular}{|c|c|c|c|c|c|c|}
\hline Faktörler & Std. $\beta$ & $t$ & $\mathbf{p}$ & $\mathbf{R}^{2}$ & $\begin{array}{c}\text { Ayarlanmış } \\
\mathbf{R}^{2}\end{array}$ & $\mathbf{F}$ \\
\hline Çalışan Davranışı & 0,396 & 13,936 & $0,000^{* *}$ & \multirow{7}{*}{0,592} & \multirow{7}{*}{0,587} & \multirow{7}{*}{$121,953^{* *}$} \\
\hline Resepsiyon Hizmetleri & 0,332 & 11,676 & $0,000^{* *}$ & & & \\
\hline Temizlik/ Hijyen & 0,240 & 8,427 & $0,000^{* * *}$ & & & \\
\hline Ödeme ve Teşvik & 0,412 & 14,486 & $0,000^{* *}$ & & & \\
\hline Sağlık ve Fitness & 0,258 & 9,073 & $0,000^{* *}$ & & & \\
\hline Kullanıma Hazırlık & 0,175 & 6,163 & $0,000^{* *}$ & & & \\
\hline Sabit & & 218,416 & $0,000^{* *}$ & & & \\
\hline
\end{tabular}

${ }^{* *} \mathrm{p}<0,01$

Araştırma katılımcılarının boş zaman ilgilenimleri ve fitness merkezine yönelik sadakatleri arasındaki ilişkileri belirlemek amacıyla çoklu regresyon analizi uygulanmıştır. Regresyona ilişkin standardize edilmiş beta $(\beta)$ değerleri incelendiğinde ödeme ve teşvik $(\beta=0,483 ; p<0,01)$ fitness merkezine yönelik sadakat üzerinde en güçlü etkiye sahip iken, çalışan davranışının da $(\beta=0,304 ; \mathrm{p}<0,01)$ fitness merkezine yönelik sadakat üzerinde önemli bir etkisi olduğu görülmektedir. Bunun yanında temizlik/hijyen ile sağlık ve fitness faktörlerinin fitness merkezine yönelik sadakat üzerinde anlamlı bir etkisi olmadığı ifade edilebilir.

Tablo 7. Katılımcıların Boş Zaman Illgilenimlerinin Fitness Merkezine Yönelik Sadakat Üzerine Etkisi

\begin{tabular}{|c|c|c|c|c|c|c|}
\hline Faktörler & Std. $\beta$ & $t$ & $\mathbf{p}$ & $\mathbf{R}^{2}$ & $\begin{array}{c}\text { Ayarlanmış } \\
\mathbf{R}^{2}\end{array}$ & $\mathbf{F}$ \\
\hline Çalışan Davranışı & 0,304 & 8,662 & $0,000^{* *}$ & \multirow{7}{*}{0,379} & \multirow{7}{*}{0,372} & \multirow{7}{*}{$51,282^{* *}$} \\
\hline Resepsiyon Hizmetleri & 0,180 & 5,141 & $0,000^{* *}$ & & & \\
\hline Temizlik/ Hijyen & 0,041 & 1,158 & 0,247 & & & \\
\hline Ödeme ve Teşvik & 0,483 & 13,747 & $0,000^{* *}$ & & & \\
\hline Sağlık ve Fitness & $-0,020$ & $-0,562$ & 0,574 & & & \\
\hline Kullanıma Hazırlık & 0,139 & 3,947 & $0,000^{* *}$ & & & \\
\hline $\begin{array}{l}\text { Sabit } \\
\text { nat }\end{array}$ & & 102,136 & $0,000^{* *}$ & & & \\
\hline
\end{tabular}


Katılımclların fitness merkezine yönelik tatminleri ve fitness merkezine yönelik sadakatleri arasındaki ilişkiyi belirlemek amacıyla yapılan çoklu regresyon analizinin $(F=50,856 ; p<0,01)$ sonucu incelendiğinde istatistiksel açıdan anlamlı bulunmuştur. Fitness merkezine yönelik tatmine ilişskin faktör "sadakat" bağımlı değişkeninin tamamının yaklaşık \% 0,09'unu açıklamaktadır. Tatminin regresyona ilişkin standardize edilmiş beta $(\beta)$ değeri $(\beta=0,296 ; p<0,01)$ göz önüne alındığında fitness merkezine yönelik tatminin fitness merkezine yönelik sadakat üzerinde etkili olduğunu söylemek mümkündür.

Tablo 8. Katılımcıların Fitness Merkezine Yönelik Tatminlerinin Fitness Merkezine Yönelik Sadakat Üzerine Etkisi

\begin{tabular}{|l|c|c|c|c|c|c|}
\hline Faktörler & Std. $\boldsymbol{\beta}$ & $\mathbf{t}$ & $\mathbf{p}$ & $\mathbf{R}^{2}$ & $\begin{array}{c}\text { Ayarlanmıs } \\
\mathbf{R}^{2}\end{array}$ & $\mathbf{F}$ \\
\hline Tatmin & 0,296 & 7,131 & $0,000^{* *}$ & 0,088 & 0,086 & $50,856^{* *}$ \\
\hline Sabit & & & & & & \\
${ }^{* *} \mathrm{p}<0,01$ & & 85,831 & $0,000^{* *}$ & & & \\
\hline
\end{tabular}

Kuramsal araştırma modeli çerçevesinde test edilen modele ilişkin sonuçlar aşağıda Şekil 2'de verilmiştir. Şekilden de görülebileceği gibi boş zaman ilgilenimi ile tatmin arasında istatistiksel olarak anlamlı bir ilişki $(\mathrm{F}=121,953 ; \mathrm{p}<0,01)$ bulunduğu, aynı şekilde boş zaman ilgilenim faktörleri ile sadakat arasında da anlamlı bir ilişkinin $(\mathrm{F}=51,282 ; \mathrm{p}<0,01)$ bulunduğu görülebilir.
Son olarak modeldeki tatmin ve sadakat arasinda da düşük düzeyli olarak karakterize edilebilecek (Ayarlanmış $\mathrm{R}^{2}=0,086$ ), ancak istatistiksel olarak anlamlı bir ilişkinin olduğu $(\mathrm{F}=50,856 ; \mathrm{p}<0,01)$ görülebilmektedir.

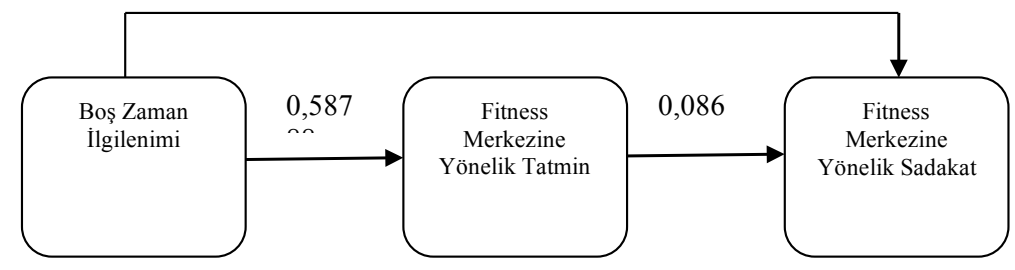

Şekil 2. Araştırmanın Modeli

\section{Sonuç ve Tartışma}

Yapılan araştırma sonucunda katılımcıların daha çok erkeklerden ve 18-25 yaş grubundan oluştuğu görülmektedir. Bunun sebebinin, fitness merkezine gelen bireylerin özellikle seçilmediği ve belirlenen farklı tarih ve saatlerdeki katılımcıların dahil edildiği göz önüne alındığında, fitness merkezi üyelerinin genel olarak erkek olduğu ve kadın üyelerin nispeten daha az olduğu düşünülmektedir. Ağyar vd. (2012, s. 21) da yaptıkları çalışmada, sportif rekreasyona katılımı cinsiyete göre karşılaştırdıklarında erkeklerin kadınlara göre spora daha fazla ilgi duyduklarını bulmuşlardır. Bunun yanında katılımcılarının çoğunluğunun üniversite öğrencisi olmasından dolayı bu yaş grubunun çalışmada ağırlıklı olduğu söylenebilir. 
Araştırmada fitness merkezi üyelerinin boş zaman ilgilenimlerine yönelik yapılan faktör analizi sonucunda ortaya altı faktör çıkmıştır. Çalışan davranıșı, resepsiyon hizmetleri, temizlik/hijyen, ödeme ve teşvik, sağllk ve fitness ile kullanıma hazırlık olarak isimlendirilmiştir. Chen vd. (2013, s. 1190)' nın ilgilenim boyutlarına ilişkin yaptıkları açıklamalardan yola çıarak, çekicilik ve merkeziliğin bu çalışmada ortaya çıkan boyutlardan dördü ile paralellik gösterdiği söylenebilir. Chen vd. (2013, s. 1190) çekiciliği aktivitenin algılanan önemi ve bireyin katıldığ 1 aktiviteden aldığı haz olarak ifade etmektedir. Bu bağlamda, ilgilenimin çekicilik boyutu ile bu çalışmada ortaya çıkan sağlık ve fitness ile temizlik/hijyen faktörlerinin ilişkili olduğu söylenebilir. Bu faktörleri oluşturan ifadelerin, bireylerin bir boş zaman aktivitesi olarak fitness merkezine gitmelerinde algıladıkları önemi içerdiği söylenebilir. Merkezilik boyutunu ise bireyin arkadaşları ve diğer önem verdiği insanlar için aktivitenin önemini ifade eden sosyal yönler olduğunu belirtmektedirler. Bu açıdan bakıldığında, bu çalışmada ortaya çıkan çalışan davranışı ve resepsiyon hizmetleri faktörlerinin ilgilenimin merkezilik boyutu ile ilişkili olduğu söylenebilir. Bu iki faktöre ait ifadelerde bireylerin fitness merkezinde çalışanlar ile resepsiyon hizmetlerine yönelik ilişkilerindeki sosyal yönlerinin ön plana çıktığı görülmektedir. Bu faktörlerden çal1şan davranışının açıklanan varyansın büyük bir bölümünü açıklamakta olması bu faktörün önemine dikkat çekmektedir. Benzer şekilde Arpacı vd. (2007, s. 7) 142 otel yönetici ve personeli ile yaptığı çalışmada müşterilerin otelden memnun ayrılmasında yönetici ve personel davranışlarının önemli etkisi olduğunu ortaya çıkarmışlardır.

Boş zaman ilgilenimi faktör ortalamaları değerlendirildiğinde sağlık ve fitness ilk sırada yer alırken, temizlik/ hijyen son sirada bulunmaktadır. Ortaya çıkan altı faktörün kendi aralarındaki korelasyon matrisi analizinde tüm faktörler arasında anlamlı bir ilişkinin olduğu ortaya çıkmıştır. Ortaya çıkan bu faktörler ile literatürde yapılan çalışmalar (Jung, 2007) arasında paralellik olduğu görülmektedir. Jung (2007)'un yapmış olduğu çalışmada boş zaman ilgilenimine ilişkin "tesisler", "çalışan davranışı", "sağlık ve fitness" ile "ödeme ve teşvik" olmak üzere dört faktör ortaya çıkmıştır. Buna göre çalışan davranışı, sağlık ve fitness ile ödeme ve teşvik faktörleri bu çalışmada ortaya çıkan faktörlerle uyum göstermektedir. Yap1lan bu çalışmadan farklı olarak tesisler faktörünü ortaya koyarken, bu araştırmada ise resepsiyon hizmetleri, temizlik/ hijyen ve kullanıma hazırlık faktörleri ortaya çıkmıştır. Bunun yanında, katılımcıların fitness merkezine yönelik tatmin ve sadakatlerine ilişkin yapılan faktör analizi sonucu ortaya çıkan iki boyut sirasiyla sadakat ve tatmin olarak isimlendirilmiştir. Her iki faktörün aritmetik ortalamasına göre tatmin faktörü daha yüksek bir ortalamaya sahiptir. Buna göre fitness merkezi üyelerinin merkeze karş1 tatmininin daha fazla olduğu söylenebilir. Ayrıca iki faktörün kendi aralarındaki korelasyon matrisi analizinde iki faktör arasında anlamlı bir ilişkinin olduğu ortaya çıkmıştır. Çatı ve Koçoğlu (2008, s. 183) yaptıkları çalışmada müşterilerin tatminlerini etkileyen faktörlerle tutumsal ve davranışsal sadakatleri arasında anlamlı bir iliş̧kinin olduğunu bulmuşlardır.

Katılımcıların boş zaman ilgilenim faktörleri ile fitness merkezine yönelik sadakati arasındaki ilişkiyi ortaya koymak amaciyla uygulanan çoklu regresyon analizi sonucunda çalışan davranışı, resepsiyon hizmetleri, ödeme ve teşvik ile kullanıma hazırlık faktörlerinin fitness merkezine yönelik sadakat üzerinde etkili olduğu ortaya çıkarken, temizlik/ hijyen ile sağlık ve fitness faktörlerinin sadakat üzerinde etkisi olmadığı sonucuna ulaşılmıştır. Bunun yanında her bir faktörün katılımcıların tatminleri üzerinde etkili olduğu ortaya çıkmıştır. Ayrıca yapılan regresyon analizi sonucunda, katılımcıların fitness merkezine yönelik tatminlerinin sadakatleri üzerinde etkili olduğu fakat oranının düşük olduğu görülmektedir. Bunun nedeninin işletmeler arasındaki rekabet, üyelik kampanyaları, fitness merkezlerindeki malzemelerin işlevselliği ve düzenli aralıklarla bakımı ve yenilenmesi gibi faktörlerin bireylerin tatminleri üzerindeki olumsuz etkilerinden kaynaklandığı düşünülmektedir.

$\mathrm{Bu}$ sonuçlar doğrultusunda, ortaya çıkan faktörler işletmeler açısından da bulundukları rekabet ortamında varlığını sürdürebilmek adına yeni müşteriler kazanmanın yanı sıra var olan müşterilerini de elde tutmak için önem teşkil etmektedir. İşletmeler bunu ancak müşterilerin ihtiyaçlarını, beklentilerini en iyi şekilde belirleyerek bunları karşılama konusunda hizmet kalitelerini geliştirerek başarı sağlayabileceklerdir. Fakat yeni müşteri kazanmak var olan müşterileri elde tutmaktan her zaman daha maliyetli olacağından işletmelerin öncelikle var olan müşterilerini korumak için müşteri sadakati geliştirmeleri gerek- 
mektedir. Bunu gerçekleştirmedeki en önemli etken ise müşteri tatmini olduğunu söylemek mümkündür. Eğer müşteri işletmeye karşı tatmin olursa müşteri işletmeye karşı sadakatte hissedecektir. Bu nedenle bu faktörleri ortaya koymak ve bu faktörlerin tatmin ve sadakat üzerindeki etkisini belirlemek bu çalışma için önem teşkil etmektedir.

\section{Sınırlılıklar ve Öneriler}

Araştırma 6 Mayıs 2013 ve 26 Ocak 2014 tarihleri ile sinırlıdır. Araştırma, Eskişehir ilinde belirlenen beş fitness merkezini kapsamaktadır. Nihai araştırma, 5 Kasım 2013 ile 26 Ocak 2014 tarihleri arasında gerçekleştirilmiştir. Araştırma, araştırma yapılan tarihlerdeki fitness merkezlerindeki üye sayıları ile sınırlıdır. Müşterilerin ihtiyaçlarının, beklentilerinin en iyi şekilde belirlenmesi müşteriye özel alternatif programlar sunum fırsatı yaratabilir. Müşteri tatmini yaratmada personelin göz ardı edilemez rolü olduğundan, işletmeler ya personeline alanı ile ilgili eğitim imkanı sunmalı ya da alanında eğitimli personel tercih etmelidir. Gelecekte bu alanda yapılacak çalışmalarda daha fazla sayıda fitness merkezinin ve katılımcısının olduğu örneklemlerin araştırmaya dahil edilmesi genellenebilirliği arttıracaktır.

\section{Kaynakça}

Argan, M. (2007). Eğlence Pazarlaması. Ankara: Detay.

Arpacı, F., Tokyürek, Ş., Çelik, B. (2007). Kat Hizmetlerinde Çalışan Personelin Davranışlarına İlişkin Yönetici ve Personel Görüşlerinin Karşılaştırılmas1. Gazi Üniversitesi Ticaret ve Turizm Eğitim Fakültesi Dergisi, 2, 1-10.

Ağyar, E., Kalkan, A., Çerez, H. (2012). Sağlık Çalışanlarının Sportif Rekreasyona Katılımlarının İncelenmesi (Antalya Araştırma ve Eğitim Hastanesi Örneği). I. Rekreasyon Araştırmaları Kongresi, Kemer/ Antalya, 15-29.

Assael, H. (1992). Consumer Behaviour \& Marketing Action. 4th Edt., Sevtap Ünal, (2008). İçgüdüsel Alışveriş içinde (s. 51), Ankara: Detay.
Beard, J., Ragheb. M. (1980). Measuring Leisure Satisfaction. Journal of Leisure Research. 12(1), 20-33. doi: $10.1177 / 004728758001900257$.

Chen, Y.C., Li, R.H., Chen, S.H. (2013). Relationships Among Adolescents' Leisure Motivation, Leisure Involvement, and Leisure Satisfaction: A Structural Equation Model. Social Indicatiors Research, 110 (3), 1187-1199. doi: 10.1007/s 11205-011-9979-2.

Castaneda, J.A. (2011). Relationship Between Customer Satisfaction and Loyalty on the Internet. J Bus Psychol, 26, 371-383. doi: 10.1007/s 10869-0109196-Z.

Çatı, K., Koçoğlu, C.M. (2008). Müşteri Sadakati ile Müşteri Tatmini Arasındaki İlişkiyi Belirlemeye Yönelik Bir Araştırma. Selçuk Üniversitesi Sosyal Bilimler Enstitüsü Dergisi, 19, 167-188.

Decloe, M.D., Kaczynski, A.T., Havitz, M.E. (2009). Social Participation, Flow and Situational Involvement in Recreational Physical Activity. Journal of Leisure Research, 41 (1), 73-90.

Evans, M.J., Jamal, A., Foxall, G.R. (2006). Individual Aspects of Consumer Behaviour. New Jersey: J. Wiley.

Funk, D.C., Ridinger, L.L., Moorman, A.M. (2004). Exploring Origins of Involvement: Understanding the Relationship Between Consumer Motives and Involvement with Professional Sport Teams. Leisure Science, 26 (1), 35-61. doi: 10.1080/01490400490272440.

Gegez, A.E. (2007). Pazarlama Araștırmaları. İstanbul: Beta.

Havitz, M.E., Dimanche, F. (1999). Leisure Involvement Revisited: Drive Properties and Padoxes. Journal of Leisure Research. 31, 122-149.

Hsieh, T.C. (2007). Recreational Motivation, Sensation Seeking, and Recreational Involvement of Taiwans' Adventure Recreation Participants. University of the Incarnate Word, ProQuest, UMI Dissertations Publishing. 
Iwasaki, Y., Havitz, M.E. (2004). Examining Relationships Between Leisure Involvement, Psychological Commitment, and Loyalty to a Recreation Agency. Journal of Leisure Research, 36 (1), 45-72.

Jamrozy, U., Backman, S.J., Backman, K.F. (1996). Involvement and Opinion Leadership in Tourism. Annas of Tourism Research, 23 (4), 908-924. doi:10.1016/0160-7383(96)000229.

Jung, Guo-Ming (2007). Structural Equation Modeling Between Leisure Involvement, Consumer Satisfaction, and Behavioral Loyalty in Fitness Centers in Taiwan. (Yayınlanmamıs doktora tezi). United States Sport Academy, Alabama.

Karalar, R. (2011). Tüketici Karar Verme Süreci: Sorunun Belirlenmesi ve Bilgilerin Araştırılması. Rıdvan Karalar (Ed.), Tüketici Davranışları içinde (s. 243-248). Eskişehir: T.C. Anadolu Üniversitesi Açıköğretim Fakültesi.

Kerstetter, D.L., Kovich, G.M. (1997). The Involvement Profiles of Division I Women's Basketball Spectators. Journal of Sport Management, 11, 234-249.

Koç, E. (2012). Tüketici Davranışı ve Pazarlama Stratejileri: Global ve Yerel Yaklaşım. (4.Baskı). Ankara: Seçkin.

Kontogianni, E. (2011). Involvement and Loyalty in Recreation Swimming in Greece: Investigating Relationsips. International Journal of Sport Management, Recreation \& Tourism, (8), 13-34. doi: 10.5199/ijsmart-1791-874X-8b.

Kurulgan, M., Argan, M. (2006). Yeni Kitap Seçiminde Etkili Olan Biçimsel Faktörlerin Okuyucu Perspektifinden Değerlendirilmesi. Bilgi Dünyası 7 (2), 230-249.

Kyle, G., Absher, J.D., Hammitt, W.E., Cavin, J. (2006). An Examination of the Motivation-Involvement Relationship. Leisure Sciences: An Interdisciplinary Journal, 28 (5), 467-485.
Kyle, G., Absher, J., Norman, W., Hammit, W., Jodice, L. (2007). A Modified Involvement Scale. Leisure Studies. 26 (4), 399-427. doi: $10.1080 / 02614360600896668$.

Lee, J., Graefe, A. (2002). Psychological Commitment as a Mediator of the Relationship Between Involvement and Loyalty. (Tech. Report No. 289). Newtown: Northeastern Research Station.

Mechinda, P., Serirat, S., Gulid, N. (2009). An Examination of Tourists' Attitudinal and Behavioral Loyalty: Comparison Between Domestic and International Tourists. Journal of Vacation Marketing, 15 (2), 129-148. doi: 10.1177/1356766708100820.

Nunnally, J.C., Bernstein, I. (1994). Psychometric Theory. Newyork: McGraw- Hall.

Odabaşı, Y. (1998). Tüketici Davranışı ve Pazarlama Stratejisi. Eskişehir: Anadolu Üniversitesi İşletme Fakültesi.

Olsen, S.O. (2007). Repurchase Loyalty: The Role of Involvement and Satisfaction. Psychology \& Marketing, 24 (4), 315-341. doi: 10.1002/mar.20163.

Özmen, A. (2006). Örnekleme. Ali Fuat Yüzer (Ed.), İstatistik içinde (s. 167-194). Eskişehir: T.C. Anadolu Üniversitesi Açıköğretim Fakültesi.

Park, S.H. (1996). Relationships Between Involvement and Attitudinal Loyalty Constructs in Adults Fitness Programs. Journal of Leisure Research, 28 (4), 233-250.

Pektaş, H.M., Çelik, H., Köse, S. (2009). Proje Tabanlı Öğrenme Yaklaşımı Üzerine Uygulama Güçlük Ölçeğinin Geliştirilmesi. Ahi Evran Üniversitesi Ĕ̆itim Fakültesi Dergisi, 10 (3), 111-118.

Richins, M.L., Bloch, P.H. (1986). After the New Wears off: The Temporal Context of Product Involvement. Journal of Consumer Research, 13 (2), 280-285. 
Rothschild, M.L. (1984). Perspectives on Involvement: Current Problems and Future Directions. Advances in Consumer Research, 11 (1), 216-217.

Tachis, S., Tzetzis, G. (2015). The Relationship Among Fans' Involvement, Psychological Commitment, and Loyalty in Professional Team Sports. International Journal of Sport Management, Recreation \& Tourism, 18, 1-25.

Tuu, H.H., Olsen, S.O. (2010). Ambivalence and Involvement in the Satisfaction-Repurchase Loyalty Relationship. Australasian Marketing Journal, 18 (3), 151-158. doi:10.1016/j.ausmj.2010.03.002.
Tüfekçi, Ö. (2010). Fitness Merkezi Müşterilerinin Hizmet Kalitesine Yönelik Beklenti ve Algılarının Değerlendirilmesi. Balıkesir Üniversitesi Sosyal Bilimler Enstitüsü, Beden Eğitimi ve Spor Anabilim Dalı (Yüksek Lisans Tezi).

Zaichkowsky, J.L. (1985). Measuring the Involvement Construct. Journal of Consumer Research, 12 (3), 341-352.

Zetou, E., Kouli, O., Psarras, A., Tzetzis, G., Michalopoulou, M. (2013). The Role of Involvement in the Loyalty of Sport Fans in Professional Volleyball. International Journal of Sport Management, Recreation and Tourism, 12, 1-16. doi: 10.5199/ijsmart1791-874X-12a. 